\title{
"What Are The Challenges of Treating Mentally Impaired Patients in The Era of a Pandemic?" : Qualitative Exploration Caregivers
}

Ah Yusuf ( $\nabla$ ah-yusuf@fkp.unair.ac.id )

Airlangga University: Universitas Airlangga https://orcid.org/0000-0002-6669-0767

Joel Rey U. Acob

Visayas State University

Roro Dian Tristiana

Airlangga University: Universitas Airlangga

Intan Faizatun Nafisa

Airlangga University: Universitas Airlangga

Verantika Setya Putri

Airlangga University: Universitas Airlangga

Siti Kotijah

STIKES Bina Sehat PPNI Mojokerto: Sekolah Tinggi Ilmu Kesehatan Bina Sehat PPNI Mojokerto

Fitriana Kurniasari Solikhah

Poltekkes Depkes Malang: Poltekkes Kemenkes Malang

Ronal Surya Aditya

Sekolah Tinggi Ilmu Kesehatan Kepanjen

Research article

Keywords: Caregivers, COVID-19, Qualitative Research, Mental Disorders

Posted Date: June 16th, 2021

DOI: https://doi.org/10.21203/rs.3.rs-607129/v1

License: (c) (1) This work is licensed under a Creative Commons Attribution 4.0 International License.

Read Full License 


\section{Abstract}

Introduction: Caregivers provide support for mental disorders in the form of care such as assistance in daily life activities, but during a pandemic it is a challenge in itself. Objective: To explore the caregiver's experience in caring for clients with mental disorders in remote areas during a pandemic.

Methods: Using a phenomenological qualitative research design with 25 participants. The sampling technique used was purposive sampling with data collection techniques using in-depth interviews and field notes then analyzed using IPA (Interpretative Phenomenological Analysis).

Results: This study found 6 themes, namely: Caregiver Workload and Tension, Threats to Caregivers' Physical and Psychological Well-Being, The Need for a Continuing Family Role, Holistic Care, Coping Strategy, Communication is getting harder.

Conclusion: our research provides unique findings about the experience of treating mental disorders needs during the COVID-19 pandemic. Caregivers of mental disorders struggle with parenting difficulties during the pandemic, which poses a threat to their well-being and potential harm to the mental disorder survivor-caregiver relationship.

\section{Introduction}

The delivery of healthcare is being challenged as the coronavirus disease 2019 (COVID-19) sweeps across the globe [1]. led to a rapid increase in cases world wide, by imposing widespread national or citywide lockdowns and strict social distancing measures [2]. These measures to reduce the spread of COVID-19 have inevitably created challenges for the delivery of health care services to people with longterm care needs such as mental illness management .

Distress and fear in the larger community due to isolation and quarantine, essential during a pandemic. People with mental disorders have been shown to experience higher levels of stress, anxiety, and depression. People with the disorder are generally more susceptible to COVID-19 [3]. They may not understand information about COVID - 19 and may have difficulty following safety procedures such as wearing masks and maintaining personal hygiene. Those with mental disorders may also have limited access to health services and hospitals [4].

Hence, concern that client health outcomes will be negatively affected is a current disruption facing the delivery of health care services. The World Health Organization (WHO) has around 450 million people with mental disorders in the world with the proportion of years of living with disabilities (YLD) of $14.4 \%$. The prevalence of households with household members with schizophrenia or psychosis in Indonesia is $7 \%$, with the highest prevalence (11\%) in Bali Province and the lowest (3\%) in the Riau Islands Province. Meanwhile, the prevalence of mental-emotional disorders in the population of East Java Province aged $\geq$ 15 years is $6.82 \%{ }^{(4)}$. The prevalence of Mojokerto Regency, in this case, is less than $5 \%$. 
The severity of mental disorders, behavioral symptoms, time spent caring for, being a female caregiver, and reducing work have all been associated with increased caregiver burden [5]. The needs of caregivers and people with mental disorders were numerous even before the pandemic, including, building capacity in health services, mental-friendly services, and cost-effective services [6]. Although there is not much literature on the treatment of mental disorders during disasters around the world, very little is known about the experiences of caregivers of mental disorders during the COVID-19 pandemic. In this paper, we describe the experiences and needs of caregivers of people with mental disorders during the COVID-19 pandemic and lockdown in a city in Indonesia. We present their challenges during the COVID-19 pandemic.

\section{Method}

The qualitative interview data that support the findings of this study are available from the corresponding author upon reasonable request.

\section{Participant}

aregivers were recruited from a mental health service set up by a non-governmental organization, in Mojokerto, Indonesia. mental disorder patients registered in the database and viewed between 21 December 2020 to 21 January 2021

Purposive sampling was used to include different socio-economic backgrounds, severity, and types of mental disorders, and to obtain an equal gender distribution (both caregivers and persons with disabilities). Monthly household income is used to determine socioeconomic status. The inclusion criteria are:

1. Caregiver who is a permanent employee;

2. Aged $20-75$ years;

3. Provided assistance to clients with mental disorders at open houses;

4. Provided care assistance for more than one month.

\section{Data Collection}

Individual semi-structured interviews were conducted with 25 participants from December 2021 to January 2021. Participant demographic data were collected at the start of each interview, gender, diagnosis of mental disorders, and level of current caregiver assistance required. We complete data collection to the point when no significant new findings emerge, and information redundancy is achieved (ie, at the 15th interview). Because of the measure of social distancing, the second author conducted face-to-face interviews using health protocols, each lasting about one hour. Interviews were audio recorded with participant consent. The writing of memos that captures the interviewer's direct interpretation and questions about the interviewee's answers during the interview was also used as a 
source of additional data. Ethical approval for this research through the ethics committee of Universitas Airlangga and verbal consent from the participants were received.

\section{Data Analysis}

Data analysis began immediately after each interview. The interviews were transcribed verbatim for analysis. Using the ID analytical guideline, we inductively coded the transcribed interviews and memos. Initial and focused coding approaches were adopted for a systematic coding process. Constant comparison strategy was also used to facilitate the systematic process. During the coding process, we focused on generat- ing themes that correspond to knowledge needs among health care professionals, with our epistemological stance on health care disciplines [7]. NVivo12 (QSR International) was used to manage the interview data and assist the coding process. The quality of data analysis (ie, rigor) was assured in the 4 aspects in the ID guideline: epistemological integrity, representative credibility, analytic logic, and interpretive authority.

\section{Results}

\section{Participant Characteristics}

A total of 15 primary caregivers aged 28 to 72 (mean age: $55.96 \pm 11.28$ ) were recruited in the study, of whom 92\% $(n=23)$ were women and 68\% $(n=17)$ (Table 1). We identified 6 themes and 19 subthemes from the interviews (Table 2). 
Table 1

Characteristics of participants

\begin{tabular}{|c|c|c|c|c|c|c|c|}
\hline Code & $\begin{array}{l}\text { Age } \\
\text { (Years) }\end{array}$ & Gender & Religion & Education & Employment & $\begin{array}{l}\text { Marital } \\
\text { Status }\end{array}$ & $\begin{array}{l}\text { Length of } \\
\text { Employment }\end{array}$ \\
\hline P1 & 22 & Women & Islam & $\begin{array}{l}\text { Vocational } \\
\text { Nurse }\end{array}$ & Nurse & Single & 3 Month \\
\hline P2 & 21 & Women & Islam & $\begin{array}{l}\text { Vocational } \\
\text { Nurse }\end{array}$ & Nurse & Single & 3 Month \\
\hline P3 & 40 & Men & Islam & $\begin{array}{l}\text { Senior High } \\
\text { School }\end{array}$ & $\begin{array}{l}\text { Private } \\
\text { employees }\end{array}$ & Married & 1 Years \\
\hline P4 & 20 & Women & Islam & $\begin{array}{l}\text { Vocational } \\
\text { Nurse }\end{array}$ & Nurse & Single & 4 Month \\
\hline P5 & 20 & Women & Islam & $\begin{array}{l}\text { Vocational } \\
\text { Nurse }\end{array}$ & Nurse & Single & 4 Month \\
\hline P6 & 28 & Women & Islam & $\begin{array}{l}\text { Bachelor of } \\
\text { Education }\end{array}$ & Teacher & Married & 1 Years \\
\hline P7 & 41 & Men & Islam & $\begin{array}{l}\text { Bachelor of } \\
\text { Education }\end{array}$ & Teacher & Married & 1 Years \\
\hline P8 & 38 & Women & Islam & $\begin{array}{l}\text { Bachelor of } \\
\text { Education }\end{array}$ & Teacher & Married & 1 Years \\
\hline P9 & 20 & Women & Islam & $\begin{array}{l}\text { Vocational } \\
\text { Nurse }\end{array}$ & Nurse & Single & 4 Month \\
\hline P10 & 34 & Men & Islam & $\begin{array}{l}\text { Senior High } \\
\text { School }\end{array}$ & $\begin{array}{l}\text { Private } \\
\text { employees }\end{array}$ & Married & 1 Years \\
\hline P11 & 22 & Women & Islam & $\begin{array}{l}\text { Vocational } \\
\text { Nurse }\end{array}$ & Nurse & Single & 3 Month \\
\hline P12 & 21 & Women & Islam & $\begin{array}{l}\text { Vocational } \\
\text { Nurse }\end{array}$ & Nurse & Single & 3 Month \\
\hline P13 & 40 & Men & Islam & $\begin{array}{l}\text { Senior High } \\
\text { School }\end{array}$ & $\begin{array}{l}\text { Private } \\
\text { employees }\end{array}$ & Married & 1 Years \\
\hline P14 & 20 & Women & Islam & $\begin{array}{l}\text { Vocational } \\
\text { Nurse }\end{array}$ & Nurse & Single & 4 Month \\
\hline P15 & 20 & Women & Islam & $\begin{array}{l}\text { Vocational } \\
\text { Nurse }\end{array}$ & Nurse & Single & 4 Month \\
\hline P16 & 28 & Women & Islam & $\begin{array}{l}\text { Bachelor of } \\
\text { Education }\end{array}$ & Teacher & Married & 1 Years \\
\hline P17 & 41 & Men & Islam & $\begin{array}{l}\text { Bachelor of } \\
\text { Education }\end{array}$ & Teacher & Married & 1 Years \\
\hline
\end{tabular}




\begin{tabular}{|llllllll|}
\hline Code & $\begin{array}{l}\text { Age } \\
\text { (Years) }\end{array}$ & Gender & Religion & Education & Employment & $\begin{array}{l}\text { Marital } \\
\text { Status }\end{array}$ & $\begin{array}{l}\text { Length of } \\
\text { Employment }\end{array}$ \\
\hline P18 & 38 & Women & Islam & $\begin{array}{l}\text { Bachelor of } \\
\text { Education }\end{array}$ & Teacher & Married & 1 Years \\
\hline P19 & 20 & Women & Islam & $\begin{array}{l}\text { Vocational } \\
\text { Nurse }\end{array}$ & Nurse & Single & 4 Month \\
P20 & 34 & Men & Islam & $\begin{array}{l}\text { Senior High } \\
\text { School }\end{array}$ & $\begin{array}{l}\text { Private } \\
\text { employees }\end{array}$ & Married & 1 Years \\
\hline P21 & 22 & Women & Islam & $\begin{array}{l}\text { Vocational } \\
\text { Nurse }\end{array}$ & Nurse & Single & 3 Month \\
\hline P22 & 21 & Women & Islam & $\begin{array}{l}\text { Vocational } \\
\text { Nurse }\end{array}$ & Nurse & Single & 3 Month \\
\hline P23 & 40 & Men & Islam & $\begin{array}{l}\text { Senior High } \\
\text { School }\end{array}$ & $\begin{array}{l}\text { Private } \\
\text { employees }\end{array}$ & Married & 1 Years \\
\hline P24 & 20 & Women & Islam & $\begin{array}{l}\text { Vocational } \\
\text { Nurse }\end{array}$ & Nurse & Single & 4 Month \\
\hline P25 & 20 & Women & Islam & $\begin{array}{l}\text { Vocational } \\
\text { Nurse }\end{array}$ & Nurse & Single & 4 Month \\
\hline
\end{tabular}


Table 2

Theme findings

\begin{tabular}{|c|c|c|}
\hline NO & THEME & SUB-THEME \\
\hline \multirow[t]{5}{*}{1} & \multirow[t]{5}{*}{ Caregiver Workload and Tension } & 1. Providing $24-$ Hour \\
\hline & & $\begin{array}{l}\text { 2. The Addiction of People with Mental Disorders } \\
\text { Increases }\end{array}$ \\
\hline & & 3. Taking on the Role of a Rehabilitation Therapist \\
\hline & & $\begin{array}{l}\text { 4. Needed to Protect Yourself from Mentally Impaired } \\
\text { Persons and Carers From COVID-19 Infection }\end{array}$ \\
\hline & & $\begin{array}{l}\text { 5. Potential Risks of Physical and Verbal Abuse Victims } \\
\text { of Mental Disorders }\end{array}$ \\
\hline \multirow[t]{2}{*}{2} & \multirow{2}{*}{$\begin{array}{l}\text { Threats to Caregivers' Physical } \\
\text { and Psychological Well-Being }\end{array}$} & 1. Worsening Physical Fatigue \\
\hline & & $\begin{array}{l}\text { 2. Psychological Stress Due to Extra Burden and COVID- } \\
19\end{array}$ \\
\hline \multirow[t]{2}{*}{3} & \multirow[t]{2}{*}{$\begin{array}{l}\text { The Need for a Continuing Family } \\
\text { Role }\end{array}$} & $\begin{array}{l}\text { 1. Educational Needs Rehabilitation and Treatment of } \\
\text { mental disorders }\end{array}$ \\
\hline & & $\begin{array}{l}\text { 2. Resources to Protect Victims and Carers of Mental } \\
\text { Disorders }\end{array}$ \\
\hline \multirow[t]{4}{*}{4} & \multirow[t]{4}{*}{ Holistic Care } & $\begin{array}{l}\text { 1. Treatment efforts are in the form of } \\
\text { psychopharmacology }\end{array}$ \\
\hline & & 2. Therapeutic communication \\
\hline & & 3. Psychosocial therapy \\
\hline & & 4. Psychoreligious Therapy. \\
\hline \multirow[t]{4}{*}{5} & \multirow[t]{4}{*}{ Coping Strategy } & 1. Making peace with the situation \\
\hline & & 2. Praying \\
\hline & & 3. According to the words of the kiai \\
\hline & & 4. Support System \\
\hline \multirow[t]{2}{*}{6} & \multirow[t]{2}{*}{ Communication is getting harder } & 1. There is no good feedback from clients \\
\hline & & 2. There is social isolation in the patient \\
\hline
\end{tabular}

Participants in this study were caregivers at the Al Hidayah Shelter. The characteristics of the participants can be seen in the table below

Based on the research results found six main themes, namely Caregiver Workload and Tension, Threats to Caregivers' Physical and Psychological Well-Being, The Need for a Continuing Family Role, Holistic Care, Coping Strategy, Communication is getting harder. 


\section{Caregiver Workload and Tension \\ Providing 24-Hour}

Care For the mentally ill, sending the mentally ill for medical treatment usually serves as a break from their overwhelming caregiving duties. Therefore, during the pandemic, they have to provide longer treatment with less rest time.

It really felt like I was taking care of him 24 hours a day at home. When I have to take it out or when the physiotherapist came to our house, I could sit on the side and rest while watching him... but I couldn't rest because social distancing measures came into effect. even in people with mental disorders (Participant 4).

\section{The Addiction of People with Mental Disorders Increases}

Caregivers revealed that people with mental disorders became increasingly dependent during the pandemic, where sufferers more often asked for help when the caregiver was there, especially for caregivers who did not go out and work because of the pandemic.

He becomes more demanding, if he sees me around, he will call me more often, or just call me no matter what happens just because I am here... He may keep asking for food every 2 hours... Or invite him to play in the room. (Participant 22)

\section{Taking on the Role of a Rehabilitation Therapist}

In addition to providing daily essential care, participants also realized the importance of rehabilitation in the recovery of people with mental disorders. To compensate for the amount of exercise that survivors can do in rehabilitation centres, caregivers seek to take on additional roles as rehabilitation therapists. However, it is challenging for caregivers to do so, due to their lack of competence and confidence in providing rehabilitative care. Therefore, people with mental disorders are reluctant to do rehabilitation exercises with them.

I didn't exercise much with him [before the pandemic]. I rely on doctors to provide rehabilitative care... I have to help her rehab every day now. (Participant 14)

\section{Needed to Protect Yourself from Mentally Impaired Persons and Carers From COVID-19 Infection}

In view of the COVID-19 situation, caregiver emphasized that it is very risky to expose people with mental disorders to infection because they have a chronic illness. Therefore, they are taking extra precautions to protect the survivors and themselves from infection, which is characterized by increased use of hand sanitizers and disinfectants. 
Due to the pandemic, I have to clean the house every day. Even though he didn't come out, I still had to go out and do some grocery shopping... Since I went out, I had to clean myself up [when I came back]. This is very risky because he is a mentally disturbed patient. I can't carry any germs on him. I have to stay alert. (Participant 8)

\section{Potential Risks of Physical and Verbal Abuse Victims of Mental Disorders}

There is a worrying phenomenon of increasing physical and verbal conflicts with mentally ill patients, as participants will lose control of their emotions and become aggressive as the duration of treatment becomes longer.

I have to be by his side. Sometimes I scold and also try to hit him with my hand when I am really angry. It didn't happen this much before the pandemic. (Participant 17)

There are more and more conflicts going on today. It happened naturally when I lived with him for a long time. [If he doesn't respond to my request] I scold him, and I'll get mad at him... That must be happening more often now. (Participant 23)

\section{Threats to Caregivers' Physical and Psychological Well- Being}

\section{Worsening Physical Fatigue}

With extended treatment duration, increased parenting duties, and lack of nursing skills, participants experienced worsening physical fatigue and manifestations of bodily symptoms such as limb swelling and body aches.

I was tired of helping him with indoor exercises all day because my limbs were already tense from following the activities, it turned out that my physical condition was getting worse. (Participant 9) Psychological Stress Due to Extra Burden and COVID-19

Carers of mentally ill patients are experiencing increased psychological stress during COVID-19. So, they feel frustrated and angry when doing maintenance tasks.

I must have felt unhappy [during the pandemic]. I wanted to help him, but I couldn't. It's actually for his own good, but he doesn't accept [my help]. (Participant 5)

I'm getting more and more angry and upset... It seems I don't have time to rest... I have to be by his side now, it makes me very stressed and a little nervous. (Participant 1)

The pandemic brings stressful life situations for caregivers, including worrying about contracting and feeling stressed due to reduced social activities due to social distancing. 
I feel stressed and worried about getting infected...I was worried about not being able to take care of the patient if anything happened to me, I became even more anxious. (Participant 13)

COVID-19 is affecting [my social activities]. I used to go to restaurants on Sundays, where I could at least chat with a group of people and eat and relax for a bit, but now I end up treating patients indoors all day... It's stressful. (Participant 16)

\section{The Need for a Continuing Family Role}

\section{Educational Needs Rehabilitation and Treatment of mental disorders}

Despite the stress and difficulties faced, caregivers said that families would continue their care role for as long as they could, as they saw caring for their family members as in their nature.

The responsibility of taking care of her like my mother took care of before, I arrange whatever she needs now... she is a part of our family, I want to give her the best care I can. (Participant 10)

They further stated the need to acquire general skills in the treatment of mental disorders and training to provide care for mental disorders.

It is not effective to rely solely on psychology or health workers. They should really inform us how to do the rehab exercises [during this pandemic]. (Participant 11)

\section{Resources to Protect Victims and Carers of Mental Disorders}

caregivers find it difficult to purchase and find hygiene products such as masks and hand sanitizer, which they need to protect themselves from infection and perform routine care tasks.

We don't have enough hygiene products... We really need to wear masks [when we go out for exercise]. We don't venture out when we don't have enough masks. (Participant 13)

We don't have enough masks... We reuse each mask at least 3 times. It's not healthy, but you have no choice, you can't buy or compete with others. (Participant 21)

\section{Holistic Care}

\section{Treatment efforts are in the form of psychopharmacology}

Participants stated that the strategy of giving drugs to clients with mental disorders was carried out in various ways. Some are given directly, some are given with the delivery of drugs are vitamins, through the patient's sugar, through food, and through drinks. This is done by the caregiver for the shelter because not all clients with mental disorders are aware and willing to take medication regularly. 
In this study, information was obtained from participants regarding drug administration strategies

"...Like Ms. D doesn't want to take medicine, so the medicine is put in sugar..." (Participant 24).

\section{Therapeutic communication}

Participants apply nonverbal therapeutic communication by evoking emotional responses, with clear and concise language, applying appropriate timing and relevance. Caregivers often use non-verbal communication techniques when communicating with clients with mental disorders. This type of communication is haptic or by touching, embracing, and holding hands that is done to build a trusting relationship.

"They are more comfortable when there is a polite touch, because they will be more trusting" (Participant 25)

The use of verbal type of therapeutic communication delivered by Participants mentioned the existence of such as inviting in interesting conversations, motivation, seduction to feel at home and conveying messages little by little. Verbal therapeutic communication carried out by halfway caregivers such as starting conversations that attract participants' attention, motivation to carry out daily activities, and conveying religious knowledge little by little according to the situation and conditions experienced by the client.

"Seducing them is a sure thing so that they want to take drugs or drugs" (Participants 2, 4, 5, 7, 9, 10) Psychosocial therapy

Patients must be able to re-adapt to their social environment, be able to take care of themselves, be able to be independent and not depend on others.

"I must also be able to provide psychosocial therapy so that they are able to be independent, as well as teach their families" (participant 13)

Psychoreligious Therapy.

The results of the study indicate that there is an effort to care for halfway house caregivers with psychoreligious therapy. Psychoreligious therapy treatment efforts such as five daily prayers, prayer, religious lectures, and tattoo therapy.

"We treat clients with mental disorders like family and treat clients with mental disorders like friends" (Participants 6 and 10).

"we pay attention by humanizing people" (Participants 5 and 7).

\section{Coping Strategy}

\section{Making peace with the situation}


Coping strategies used by caregivers when finding obstacles in caring for clients with mental disorders, namely making peace.

"We try to make peace with the situation when we experience difficulties in treating clients with mental disorders" (participant 5).

\section{Praying}

The next adaptive coping strategy is praying by saying istighfar, Al Fatihah, dhikr, and taking lessons from events that have occurred.

"We have basic education in Islamic boarding schools so praying is one of the coping methods we do when we face difficulties in treating clients with mental disorders" (participant 9).

\section{According to the words of the kiai}

Expressing remembering the advice of the kyai when he was at the Islamic boarding school, remembering the nurse oath that had been uttered, intending to carry out work for Allah SWT

"I always remember what the kiai said about all doing anything for the sake of Allah" participant 2

"We also remember the nurse's oath that she once said when she graduated from nursing education, so there is guilt if the client does not carry out her role as a caregive" (Participant 3).

\section{Support System}

Coping strategies by seeking support are usually obtained from husbands, psychiatrists, and caregivers.

"I will usually tell the problems and difficulties during treatment to someone who is considered capable of providing solutions and support" (Participant 1).

The results of this study also identified a coping strategy shown by the caregiver by avoiding.

"When I feel uncomfortable with the client it is better to leave and not respond to the client" (participant 4).

\section{Communication is getting harder}

\section{There is no good feedback from clients}

Someone with a mental disorder will be very difficult to communicate with if the patient is in an unstable condition, especially when the patient lacks communication due to restrictions on meeting people. So they will remain in their previous state.

"...I try to always invite communication, but since the pandemic and rarely meet people for communication, it makes it difficult for them to provide feedback when communicating"(Participant 2) 


\section{There is social isolation in the patient}

The condition alone in the room causes the patient to be affected by his own thoughts, especially the patient who has not been able to control his mind and himself. Outside activities are starting to be limited and meetings with fellow patients are also limited, making all of this difficult.

"...I feel for myself how difficult it is to treat mental disorders during a pandemic, because treatment with drugs is not enough, but socialization is very helpful" (participant 3)

\section{Discussion}

We identified the experiences of caregivers of stroke families during the COVID-19 pandemic, and these experiences were categorized into 6 themes: difficulty of care services, workload and additional caregiving tensions, threatened relationships between caregivers and stroke survivors, threats to caregivers' physical health. and psychological well-being, and the need to continue in a nurturing role [5]. One of the impacts of the COVID-19 pandemic on caregivers of mental disorders is the increased physical burden. Closure of rehabilitation and child care centers in Hong Kong. means that people with mental disorders are no longer able to receive therapy, resulting in a decrease in their function and an increase in dependence on caregivers [4]. This situation is exacerbated by social isolation and the act of working from home, as participants have to provide longer care for their family members with reduced informal and formal support. hours of care are known to be generally higher for single caregivers and those living with care recipients, therefore making them more susceptible to burnout from trying to meet work and increasing demands for care simultaneously in their homes and jobs during the pandemic [2]. Support service retirement also leaves participants without the opportunity to take a break from their piled up parenting duties, because they reported poorer physical health and fatigue when caring for people with mental disorders during the COVID-19 pandemic [8].

In addition, because people with mental disorders and people with multiple comorbidities are more susceptible to COVID-19 infection, caregivers feel obligated to be involved in Hygiene practices such as disinfecting the environment more often add to the burden of their caregiving duties. Participants also experienced psychological improvement and emotional burden during the pandemic [3]. While many caregivers of mental disorders are already experiencing psychological stress in connection with their extraordinary caregiver role, the uncertainty surrounding the COVID-19 pandemic has increased the suffering of participants, placing them at higher risk for anxiety and depression. Participants reported similar concerns about infection and transmission of COVID-19 with previous studies, as and concerns over unemployment, reduced income, and increased spending on hygiene products [9]. Studies show that social support can reduce the psychological distress and risk of patient abuse and act as a buffer against physical and mental illness [10]. While participants in this study previously had the opportunity to take a break from parenting duties and relieve stress by meeting up with family and friends, social distancing measures have isolated participants and limited the support they receive from their social support network, contributing to stress higher [11]. 
In this study, the alarming situation of increasing the risk and frequency of harassment is revealed. Social isolation, increased patient dependence, and time demands during a pandemic have been shown to increase patients' susceptibility to abuse from caregivers, which is similar to the accounts of participants in this study [12]'[13]. Economic pressures and forced closeness with family members during quarantine can also lead to an increased risk of aggression and domestic violence [14].

Our findings further suggest that ill-treatment of people with mental disorders has preceded, and that current parenting difficulties may have exacerbated the situation [15]. Despite the shocking difficulties, the caregivers expressed their commitment to continuing the role of care for their mentally ill patients, as a way to repay the care they had received themselves from the survivors [16]. This is similar to the findings of previous studies, where caregivers maintained a nurturing role despite deteriorating health. Indonesia's traditional culture in the future emphasizes collective interests and values of filial piety committed to the family, and plays a key role in making decisions to provide care for family members [17],[18]. Quitting the parenting role would thus be seen as a departure from the expectations of the spouse [19].

Coping strategy is defined as a certain process accompanied by an effort in order to constantly change the cognitive and/or behavioral domains to manage and control external and internal demands and pressures that are predicted to burden and exceed the abilities and resilience of the individual concerned [20]. The results of this study indicate that the coping strategies used by caregivers are adaptive. The results of this study indicate that there are adaptive coping strategies used by caregivers when finding obstacles in caring for clients with mental disorders. Caregivers try to make peace with the situation when they have difficulty in providing care to clients with mental disorders [21]. This is done so that caregivers do not feel stressed and burdened with the work they are doing. This is in line with Fitriani's research which states that caregivers' perceptions of their burdens can also affect various aspects of daily life which in turn can affect the quality of life [22].

Deliberations and discussions are constructive activities carried out by caregivers as a form of coping strategies for caregivers. Deliberations are usually carried out by the caregivers of the halfway house directly face to face or through the WhatsApp group application. Deliberations and discussions conducted by caregivers are positive things that must be carried out so that they do not become a burden on the caregiver in caring for clients with mental disorders which then affect the caregiver's quality of life. The next adaptive coping strategy is praying by saying istighfar, Al Fatihah, dhikr, and taking lessons from events that have occurred. This is in line with research by Alfiandi et al (2018) which states that religious coping affects a person's cognitive patterns to find solutions to difficult situations they face. Some caregivers have basic education in Islamic boarding schools so praying is one of the adaptive coping methods they do when facing difficulties in caring for clients with mental disorders. Participants in this study mentioned adaptive coping strategies by remembering positive things. Remembering the advice of the kyai at the Islamic boarding school, remembering the nurse's oath that was once uttered, intending to do work for the sake of Allah SWT, remembering the patient's development, self-reflection, and returning the problem to God Almighty. This is in line with the results of Dewi's research (2018) which 
identified a spiritual coping strategy by submitting and returning all the problems she experienced to God in accordance with the Book of Al-Quran Surah Yusuf verse 86.

The results of this study identify the existence of an adaptive coping strategy by seeking support. Caregiver will tell the problems and difficulties during treatment to a person who is considered capable of providing solutions and support. In this way, it is hoped that the problem will be resolved soon and not burden the caregiver [23]. This is in line with Ribe's (2018) statement which states that seeking social support for caregivers with mental disorders can reduce the risk of mental health problems and reduce the level of perceived burden [24].

The results of this study indicate that there are difficulties in the communication aspect felt by the caregiver. Yusuf (2019) explains that severe mental disorders are disturbances in thoughts, behavior and feelings that are manifested in the form of a set of symptoms and or significant behavioral changes, and can cause obstacles in carrying out human functions. Damage to social interactions experienced by schizophrenic patients is a problem due to positive and negative symptoms that must be immediately addressed with therapeutic communication so that self-isolation does not occur [25], [26]. In patients with mental disorders experience emotional disturbances that are shown through affect and mood. Affect is an external expression of one's emotions that can be seen from one's face [27].

\section{Conclussion}

To the best of our knowledge, our research provides unique findings about the experience of treating mental disorders needs during the COVID-19 pandemic. Caregivers of mental disorders struggle with parenting difficulties during the pandemic, which poses a threat to their well-being and potential harm to the mental disorder survivor-caregiver relationship. The pandemic has also exposed gaps in their stroke care knowledge and rehabilitation skills due to the suspension of formal support services, as well as their need for critical resources to protect themselves effectively from COVID-19. Support for caregivers is urgently needed to reduce their caregiving burden during the pandemic and to maintain their caregiving role.

\section{Declarations}

\section{Conflict of interest statement}

The authors declare that the research was conducted in the absence of any commercial or financial relationships that could be construed as a potential conflict of interest Author contribution statement the author contributes to providing knowledge about how caregivers treat mental patients properly, so that mental patients can recover and return to society properly

\section{Contribution to the field}


Community and psychology nursing science helps the community in improving their health status, among others, by empowering the community itself. the better and more participative the community is, the more people care about health. This study examines how the role of the caregiver in providing services to people with mental disorders, the caregiver strives for people with mental disorders to recover without recurrence and return to society, can be accepted by society. In this case the caregiver must be able to make mental disorders able to function again and independently in carrying out daily activities.

\section{Ethics statements}

Studies involving animal subjects Generated Statement: No animal studies are presented in this manuscript. Studies involving human subjects Generated Statement: The studies involving human participants were reviewed and approved by Komite Etik Fakultas Keperawatan Universitas Airlangga. The patients/participants provided their written informed consent to participate in this study. Inclusion of identifiable human data Generated Statement: No potentially identifiable human images or data is presented in this study

\section{References}

1. Lee JJ, Tsang WN, Yang SC, Kwok JYY, Lou VWQ, Lau KK. Qualitative Study of Chinese Stroke Caregivers' Caregiving Experience during the COVID-19 Pandemic. Stroke. 2021; April:1407-14.

2. Archer J, Reiboldt W, Claver M, Fay J. Caregiving in Quarantine: Evaluating the Impact of the Covid-19 Pandemic on Adult Child Informal Caregivers of a Parent. Gerontology and Geriatric Medicine. $2021 ; 7$.

3. Vaitheswaran S, Lakshminarayanan M, Ramanujam V, Sargunan S, Venkatesan S. Experiences and Needs of Caregivers of Persons With Dementia in India During the COVID-19 Pandemic-A Qualitative Study. American Journal of Geriatric Psychiatry. 2020;28:1185-94. doi:10.1016/j.jagp.2020.06.026.

4. Budnick A, Hering C, Eggert S, Teubner C, Suhr R, Kuhlmey A, et al. Informal caregivers during the COVID-19 pandemic perceive additional burden: findings from an ad-hoc survey in Germany. BMC Health Services Research. 2021;21:1-11.

5. Sheth K, Lorig K, Stewart A, Parodi JF, Ritter PL. Effects of COVID-19 on Informal Caregivers and the Development and Validation of a Scale in English and Spanish to Measure the Impact of COVID-19 on Caregivers. Journal of Applied Gerontology. 2021;40:235-43.

6. Spina S, Marrazzo F, Migliari M, Stucchi R, Sforza A, Fumagalli R. The response of Milan's Emergency Medical System to the COVID-19 outbreak in Italy. The Lancet. 2020;395:e49-50. doi:10.1016/S0140-6736(20)30493-1.

7. Yusuf A, PK FR, Tristiana RD, Aditya RS. Riset Kualitatif Dalam Keperawatan. 1st edition. Surabaya: Mitra Wacana Media; 2017.

8. Abidah A, Hidaayatullaah HN, Simamora RM, Fehabutar D, Mutakinati L. The Impact of Covid-19 to Indonesian Education and Its Relation to the Philosophy of "Merdeka Belajar. Studies in Philosophy 
of Science Education. 2020;1:38-49.

9. Greenhawt M, Chan ES, Fleischer DM, Hicks A, Wilson R, Shaker M, et al. Caregiver and expecting caregiver support for early peanut introduction guidelines. Annals of Allergy Asthma Immunology. 2018;120:620-5. doi:10.1016/j.anai.2018.03.001.

10. Galehdar N, Kamran A, Toulabi T, Heydari H. Exploring nurses ' experiences of psychological distress during care of patients with COVID-19: a qualitative study. 2020;:1-9.

11. Gérain P, Zech E. Informal Caregiver burnout? Development of a theoretical framework to understand the impact of caregiving. Front Psychol. 2019;10:JULY.

12. Tramonti F, Bonfiglio L, Bongioanni P, Belviso C, Fanciullacci C, Rossi B, et al. Caregiver burden and family functioning in different neurological diseases. Psychol Health Med. 2019;24:27-34. doi:10.1080/13548506.2018.1510131.

13. Fitryasari R, Yusuf A, Nursalam, Tristiana RD, Nihayati HE. Family members' perspective of family Resilience's risk factors in taking care of schizophrenia patients. International Journal of Nursing Sciences. 2018;5:255-61.

14. Ugalde A, Gaskin CJ, Rankin NM, Schofield P, Boltong A, Aranda S, et al. A systematic review of cancer caregiver interventions: Appraising the potential for implementation of evidence into practice. Psycho-Oncology. 2019;28:687-701.

15. de Wit J, Bakker LA, van Groenestijn AC, van den Berg LH, Schröder CD, Visser-Meily JMA, et al. Caregiver burden in amyotrophic lateral sclerosis: A systematic review. Palliative Medicine. 2018;32:231-45.

16. Pajarianto H, Kadir A, Galugu N, Sari P, Februanti S. Study from Home in the Middle of the COVID-19 Pandemic: Analysis of Religiosity, Teacher, and Parents Support Against Academic Stress. Talent Development Excellence. 2020;12:1791-807.

17. Sherifali D, Usman Ali M, Ploeg J, Markle-Reid M, Valaitis R, Bartholomew A, et al. Impact of internetbased interventions on caregiver mental health: Systematic review and meta-analysis. Journal of Medical Internet Research. 2018;20:1-12.

18. Yunita FC, Yusuf A, Nihayati HE, Hilfida NH. Coping strategies used by families in Indonesia when caring for patients with mental disorders post -pasung, based on a case study approach. General Psychiatry. 2020;33.

19. Singh JA, Upshur REG. Personal View The granting of emergency use designation to COVID-19 candidate vaccines: implications for COVID-19 vaccine trials. The Lancet Infectious Diseases. 2020;3099.

20. Mosley PE, Moodie R, Dissanayaka N. Caregiver Burden in Parkinson Disease: A Critical Review of Recent Literature. J Geriatr Psychiatry Neurol. 2017;30:235-52.

21. Liu Z, Heffernan C, Tan J. Caregiver burden: A concept analysis. International Journal of Nursing Sciences. 2020;7:438-45. doi:10.1016/j.jjnss.2020.07.012.

22. Wright R, Lowton K, Hansen BR, Grocott P. Older adult and family caregiver preferences for emergency department based-palliative care: An experience-based co-design study. International 
Journal of Nursing Studies Advances. 2021;3 December 2020:100016.

23. Shrestha N. Health System Preparedness in Tackling the COVID- 19 in Nepal: a Qualitative Study Among Frontline Healthcare Workers and Policymakers. :1-22.

24. Liu Q, Luo D, Haase JE, Guo Q, Wang XQ, Liu S, et al. Articles The experiences of health-care providers during the COVID-19 crisis in China: a qualitative study. The Lancet Global Health. 8:e7908. doi:10.1016/S2214-109X(20)30204-7.

25. Xiang YT, Zhao YJ, Liu ZH, Li XH, Zhao N, Cheung T, et al. The COVID-19 outbreak and psychiatric hospitals in China: managing challenges through mental health service reform. Int J Biol Sci. 2020;16:1741-4.

26. White CL, Overbaugh KJ, Pickering CEZ, Piernik-Yoder B, James D, Patel DI, et al. Advancing care for family caregivers of persons with dementia through caregiver and community partnerships. Research Involvement Engagement. 2018;4:1-7.

27. Cook TM. Personal protective equipment during the coronavirus disease (COVID) 2019 pandemic - a narrative review. Anaesthesia. 2020. 